lood Science and Technology Vol. 3 (1969) p. $139-149$

\title{
Aspects of Fiber Morphology Affecting Properties of Handsheets Made from Loblolly Pine Refiner Groundwood
}

\author{
By Charles W. McMillin*, Alexandria, La.
}

\section{Summary}

In Pinus laeda L., burst, breaking length, and sheet density were improved by using fiber sined from wood having long, narrow-diameter tracheids with thick walls. Only narrowiameter tracheids with thick walls were required to improve tear factor. A theoretical stress nalysis revealed that thick-walled colls of small outside diameter fail by diagonal tension or arallel shear, depending on the fibril angle, while under torsional stres during refining. Such tilures result in ribbon-like fragments which research elsewhere has demonstrated to provide 10 coherence necessary for strength development in mochanical pulps. In contrast, thinalled cells of small outside diameter fail by diagonal compreasion and yield fow ribbons. ong fibers are more desirable than short fibers beceuse of greater induced streses and im. noved chances of axial alignment between the disks.

\section{Zusammenfassung}

Berstdruck, ReiBlänge und Blattdichte von Pinus taeda L., wurden durch Verwendung von efiner-Faern aus Holz, das lange Tracheiden mit geringem Durchmeseer und dicken Wanden esitzt, verbeesert. Zur Verbeserung des Reißfaktors waren ausechließlich dickwandige recheiden mit geringem Durchmesser erforderlich. Eine Spannungsanalyse zeigte, daB dick. andige Zellen mit kleinem AuBendurchmeser durch diagonale Zug-oder parallele Schersanspruchung in Abhăngigkeit vom Fibrillenanstiegswinkel wăhrend der Torsionsbelastung a Refiner reißen. Durch diesen Bruchvorgang ergeben sich bandförmige Bruchstücke, die wchgewiesenermaßen notwendig sind, um den inneren Zusammenhalt für die Festigkeite1twicklung in mechanischem Zellstoff zu ermöglichen. Im Gegensetz hierzu brechen dünnandige Zellen mit kleinem AuBendurchmeseer mehr durch diagonale Druckbeanspruchung, nd es ergeben sich nur wenige Bänder. Lange Fasern sind ineofern erwünschter als kurze, * sie zu höheren Festigkeiten führen und eine höhere Wahrscheinlichkeit ihrer axialen Auschtung zwischen den Refinerscheiben besteht.

\section{Introduction}

A program of research to establish the interrelations between pulp quality, lemical composition, wood morphology, gross wood properties, degree of fiber fining, and the properties of paper handsheets has been undertaken at Alexanria, Louisiana. The ultimate objective is to develop criteria useful in preicting and controlling the papermaking potential of refiner groundwood from iblolly pine (Pinus taeda L.).

A previous paper [McMmLIN 1968] examined the interrelationships between fining energy, gross wood characteristics, and the physical properties of handreets. Burst, tear, and breaking length were shown to be increased by application t high refining energy and use of fast-grown wood that contains a high proportion ? latewood but is of relatively low density. Only high refining energy and high roportion of latewood were required to improve sheet density. These results

* The author appreciatively acknowledges the ascistance of the Roy O. Martin Lumber Co., lexandria, Lo.; R. A. Leask and J. ADAms of Bauer Bros. Co., Springfield, Ohio; and . Bowen, statistician at the Southern Forest Experiment Station, New Orleans, La. 
suggest that sheet properties can be improved or made more uniform by selection of wood having the desired characteristios or by modification of refining procedures in acoordance with wood quality.

Gross wood characteristics are relatively easy to measure and are therefore useful in identifying wood types. However, it is difficult to interpret these gross factors in terms of their causal relationships with sheet properties. For example, wood specific gravity is, in part, determined by the morphological characteristics of early- and latewood tracheids and the relative amounts of each tissue type. Hence, quantitative data in torms of fiber characteristics should prove more useful than specific gravity in guiding research in wood quality and in the paper technology of refiner groundwood.

This paper discusses the interrelationships between loblolly pine fiber oharacteristics and the physical properties of handsheets. Subeequent articles will consider pulp quality and chemical composition of wood in relation to handsheet strength.

\section{Procedure}

The detailed procedures for selection of trees, wood preparation and classification, refining, chip sampling, and handsheet testing have all been described previously [McMmLIN 1968] and are therefore only summarized here.

Wood was selected and stratified into 12 categories. Two growth rates (less than 6 rings per inch and more than 6 rings per inch), two speoifio gravities (less than 0.49 and more than 0.49$)$, and three radial positions in the stem $(0 \ldots 10$, $11 \ldots 20$, and $21 \ldots 30$ rings from the pith) were considered in a factorial design. The wood in each category was chipped and the chips randomly divided into four within-sample replications. The 48 samples of chips were then fiberized in a double-disk refiner; consistency was 20 parcent and refining energy was 40 hp days per air-dry ton on the first pass and $30 \mathrm{hp}$ days on the second. Identical samples of wood stratified as above were refined in a single pass, but pulpe were inferior to those obtained from double-pass fiber and therefore are not considered here.

Sinoe the purpose of the study was to establish basic relationships, no attempt was made to optimize sheet properties, for example, by applying higher refining energies. Because of the factorial nature of the experimental deaign (all combinations of all selected levels of epecific gravity, growth rate, radial position, and passes through refiner), and because of the widely divergent wood types, it was necessary to select refining energies that could achieve fiberization in all wood categories in both one and two passes. High refining energies were not possible with all wood types, i.e., with certain types high energy inputs would have resulted in zero plate clearance. Because of this necessary limitation, the double-pess pulps were of lower quality than would generally be attained in commercial practice.

Handsheets were formed by the TAPPI standard method. Four sheet properties were determined : sheet density, burst factor, tear factor, and breaking length.

A subsample of chips was drawn from each replication for determination of wood fiber characteristics. Four morphological properties were measured for both earlywood and latewood - single cell-wall thickness, radial lumen diameter, radial tracheid width, and tracheid length - and correlated with the four sheet properties. All morphological characteristics were determined on samples used in the earlier study. 
Tracheid length was evaluated from 40 randomly selected chips. Chips were lissected into earlywood and latewood slivers and macerated in a 50/50 solution of i0 percent hydrogen peroxide and glacial acetic acid for 2 days at $50^{\circ} \mathrm{C}$. Samples if the macerated material were mounted in water on 10 glass slides. With a calirated projection microscope $(\times 40)$, five tracheids were measured on each slide, he five unbroken tracheids lying adjacent to a dot on the center of the projection creen. Thus 50 observations were made on each subsample.

On different tracheids (macerated as described above) single cell-wall thickness, umen diameter, and tracheid diameter for both earlywood and latewood were eparately determined by viewing the radial fiber surface. Fifty observations of ach dimension were made at the midpoint of the tracheid $(5$ observations on each of 0 slides) with a compound microscope equipped with a Filar eyepiece. Radial urfaces were identified by the presence of pits. Thickness of both cell walls was neasured and the results averaged for each observation.

\section{Processing the Data}

To identify possible trends, individual handsheet properties were first plotted gainst the measured morphological characteristics. In most cases, no single elationship was apparent between a given sheet property and a single early- or itewood morphological characteristic. Multiple regression analysed of these data id not develop useful relations.

Since a paper handsheet is a composite of both earlywood and latewood fibers, weighting system was employed to describe average composite morphological haracteristics, e.g., average earlywood-latewood tracheid length. If the dimenions of cells in the tangential direction are assumed constant at unity, it can be hown that a given average morphological property for the earlywood and laterood composite is a function of the number of cells per unit volume of each tissue ype and their respective volume percentages. From this analysed, the following reighting equation was developed.

$$
P=\frac{\frac{(1-L W)\left(P_{e}\right)}{(E T)(\text { ETD })}+\frac{(L W)\left(P_{1}\right)}{(L T)(L T D)}}{1+\frac{(L W)}{(L T)(L T D)}}
$$

there:

' = a weighted morphological characteristic of the earlywood-latewood composite, $P_{e}=$ a corphological characteristic of earlywood, $P_{1}=$ a morphological characteristio of latewood, $W=$ proportion of latewood, ET = earlywood tracheid length (millimeters), ETD = early. ood tracheid diameter (micrometers), LT = latewood tracheid length (millimeters), LTD = ttewood tracheid diameter (micrometers).

The fiber characteristics of Table 1 were derived by this weighting procedure. 'he proportion-of-latewood values used in the weighting equation were those obsined in the earlier study, as are the handsheet properties listed in Table 1.

The data in the table were used in multiple regression analyses. Equations ere developed by stepwise introduction of the independent variables (48 obserations) in order of their individual contribution to the cumulative $R^{2}$. All equaons were of the type: $y=b_{0}+b_{1} x_{1}+b_{2} x_{2}+\cdots$, where $y$ is a dependent ariable, e.g., burst, tear; $b_{i}$, a regression coefficient; and $x_{i}$, an independent 
variable, e.g., weighted average tracheid length, weighted average cell-wall thickness. All equations were tested at the 95 percent level of probability, and all variables were significant at that level.

Various combinations and transformations of the single variables were included in the analysis.

The single variables were:

TL = weightod average tracheid length (millimetars), CWT $=$ woighted avarage cell-wall thicknes (micrometern), $\mathbf{L D}=$ woighted avarage lumen diametar (micrometors), TD = wrighted average tracheid diametor (miarometers).

The combinations and transformations were:

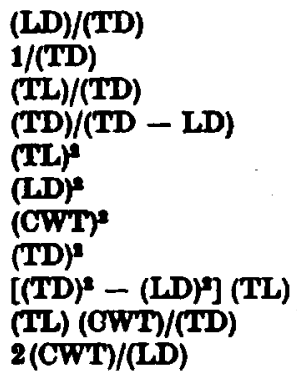

\section{Results}

Several of the morphologioal characteristics listed in Table 1 were correlated. For the 48 observations, cell-wall thickness 1 was positively correlated with tracheid length $(r=0.591)$ and negatively correlated with lumen diameter $(r=$ $-0.698)$ and tracheid diameter $(r=-0.434)$. Lumen diameter was highly correlated with tracheid diameter $(r=0.945)$. All other correlations were low.

As in the earlier study, sheet properties also proved interrelated. Sheet density was positively correlated with burst factor $(r=0.616)$, tear factor $(r=0.526)$, and breaking length $(r=0.629)$. Burst factor was positively correlated with breaking length $(r=0.962)$ and tear factor $(r=0.934)$, while tear factor was positively correlated with breaking length $(r=0.929)$. Variance analyais showed no significant difference in refining energy between pulps.

Table 2 lists multiple regression equations which most accurately describe handsheet properties in terms of weighted average morphological characteristics.

\section{Sheet Density}

The best equation for sheet density (Eq. (1)) acoounted for 17 percent of the total variation, with a standard error of 0.02 . Sheet density was significantly related to the product of tracheid length and cell-wall thickness divided by tracheid diameter.

Fig. 1 shows the effect of these variables on sheet density. This figure and Figs. 2 through 4 were obtained by substituting a range of values of the variables on the $X$-axis and fixing the remaining variables at the indicated levels. Lumen diameter varied with tracheid diameter by the lineal regression equation:

$$
\mathrm{LD}=-23.4844+1.2239 \text { (TD) } \quad\left(R^{\mathrm{a}}=\mathbf{0 . 8 9 3 )} .\right.
$$

I All morphological characteristics discussed subeoquently are woighted sverages. 
he relations plotted consider only the range of variation contained within the inge of all variables.

From Eq. (1) and Fig. 1, sheet density increased with increasing tracheid length ir all sampled levels of tracheid diameter and wall thickness. The level and slope

Table 1. Weighted Wood Characteriatics and Handsheet Properties

\begin{tabular}{c|c|r|c|c|c}
\hline $\begin{array}{c}\text { Position in } \\
\text { tree (rings } \\
\text { from pith) }\end{array}$ & $\begin{array}{c}\text { Unextracted } \\
\text { specific } \\
\text { gravity }\end{array}$ & $\begin{array}{c}\text { Rings } \\
\text { per } \\
\text { inch }\end{array}$ & $\begin{array}{c}\text { Cell wall } \\
\text { thickness }^{2} \\
\mu \mathrm{m}\end{array}$ & $\begin{array}{c}\text { Lumen } \\
\text { diameter } \\
\text { um. }\end{array}$ & $\begin{array}{c}\text { Tracheid }_{\text {width }^{2}} \\
\mu \mathrm{m}\end{array}$ \\
\hline $0-10$ & 0.427 & 4.11 & 5.4 & 38.2 & 49.0 \\
$0-10$ & .457 & 7.59 & 6.2 & 38.1 & 50.1 \\
$0-10$ & .492 & 4.80 & 6.1 & 32.5 & 44.7 \\
$0-10$ & .515 & 11.83 & 6.2 & 30.1 & 42.6 \\
$11-20$ & .445 & 5.53 & 6.7 & 34.1 & 47.5 \\
$11-20$ & .459 & 7.08 & 6.7 & 34.9 & 48.0 \\
$11-20$ & .512 & 5.30 & 7.3 & 28.6 & 43.0 \\
$11-20$ & .524 & 12.38 & 7.1 & 28.3 & 42.5 \\
$21-30$ & .458 & 4.91 & 6.6 & 33.2 & 46.6 \\
$21-30$ & .438 & 8.27 & 7.0 & 32.9 & 46.6 \\
$21-30$ & .534 & 5.53 & 7.2 & 29.7 & 43.8 \\
$21-30$ & .511 & 8.27 & 7.7 & 29.3 & 44.6
\end{tabular}

\begin{tabular}{c|c|r|r|r|r}
\hline $\begin{array}{c}\text { Position in } \\
\text { tree (rings } \\
\text { from pith) }\end{array}$ & $\begin{array}{c}\text { Tracheid } \\
\text { length } \\
\text { mm }\end{array}$ & $\begin{array}{c}\text { Sheet } \\
\text { density } \\
\text { g/cm }^{3}\end{array}$ & Burst factor & $\begin{array}{c}\text { Tear } \\
\text { factor }\end{array}$ & $\begin{array}{c}\text { Breaking } \\
\text { length }\end{array}$ \\
\hline $0-10$ & 3.53 & 0.289 & 3.34 & 41.7 & 604.3 \\
$0-10$ & 3.71 & .281 & 3.25 & 42.2 & 720.5 \\
$0-10$ & 3.34 & .266 & 3.82 & 48.9 & 761.0 \\
$0-10$ & 3.64 & .293 & 2.96 & 35.5 & 656.1 \\
$11-20$ & 3.85 & .287 & 4.41 & 54.3 & 896.1 \\
$11-20$ & 4.11 & .293 & 4.87 & 58.4 & 996.1 \\
$11-20$ & 3.73 & .318 & 6.42 & 82.2 & $1,264.0$ \\
$11-20$ & 3.73 & .292 & 3.23 & 41.3 & 724.2 \\
$21-30$ & 4.07 & .291 & 5.61 & 67.0 & $1,096.9$ \\
$21-30$ & 4.18 & .319 & 7.00 & 76.5 & $1,312.4$ \\
$21-30$ & 3.92 & .302 & 5.49 & 61.3 & $1,085.3$ \\
$21-30$ & 4.16 & .299 & 5.67 & 61.7 & $1,129.3$
\end{tabular}

1 Each numerical value is the average of four replications.

${ }^{2} \mu \mathrm{m}=$ micrometer $=10^{-s}$ millimeters $=10^{-6}$ meters.

: the sheet densitiy-tracheid length relationship increased with increasing cellall thickness but decreased with increasing tracheid diameter. Although not lown here, the effect of a variable in the denominator of a regression equation is nerally curvilinear. 
Table 2. Multiple Regression Equations Developed to Eetimate Sheet Properties

\begin{tabular}{|c|c|c|c|c|c|c|}
\hline Property & Equation & Variable & & Coetticient & Cumulative $R^{2}$ & $\begin{array}{l}\text { Standard } \\
\text { error ot } \\
\text { eatlimates }\end{array}$ \\
\hline \multirow[t]{2}{*}{ Sheet denaity } & \multirow[t]{2}{*}{1} & & $b_{0}$ & 0.2451 & \multirow[b]{2}{*}{0.169} & \multirow{3}{*}{0.02} \\
\hline & & (TD) & $b_{1}$ & 0.7350 & & \\
\hline \multirow{2}{*}{ Burst factor } & \multirow{3}{*}{2} & (TL) (CWT) & $b_{0}$ & -0.8456 & & \\
\hline & & $\begin{array}{c}\text { (TD) } \\
2 \text { (CWT) }\end{array}$ & $b_{1}$ & 15.8218 & 0.373 & \\
\hline \multirow[t]{5}{*}{ Tear factor } & & (LD) & $\begin{array}{l}b_{2} \\
b_{0}\end{array}$ & -7.1993 & 0.477 & 1.02 \\
\hline & \multirow{4}{*}{3} & 2 (CWT) & $\begin{array}{l}b_{0} \\
b_{1}\end{array}$ & $\begin{array}{r}792.2751 \\
-274.6336\end{array}$ & 0.378 & \\
\hline & & (LD) & & - & & \\
\hline & & $\overline{(\mathrm{TD})}$ & $b_{2}$ & $-1,151.4235$ & 0.434 & \\
\hline & & $(\mathrm{CWT})^{2}$ & $b_{4}$ & 1.3646 & 0.563 & 10.16 \\
\hline \multirow{7}{*}{ Breaking length } & \multirow[t]{7}{*}{4} & (TL) (CWT) & $b_{0}$ & $13,285.3726$ & & \\
\hline & & (TD) & $b_{1}$ & $3,660.5067$ & 0.453 & \\
\hline & & $\frac{2 \text { (CWT) }}{(\mathrm{LD})}$ & $b_{2}$ & $-4,602.1215$ & 0.556 & \\
\hline & & $\frac{(\mathrm{LD})}{(\mathrm{TD})}$ & & $-18,318.4190$ & 0.597 & \\
\hline & & (TD) & & & & \\
\hline & & (TD - LD) & $b_{4}$ & $537.083 i$ & 0.691 & \\
\hline & & $\frac{(\mathrm{TL})}{\text { (TD) }}$ & & $-19,569.7859$ & 0.740 & 133.20 \\
\hline
\end{tabular}

For all significant variables within the range of data, sheet density was increased by using fiber refined from wood having long tracheids with narrow diameters and thick cell walls.

\section{Burst Factor}

The best multiple regression equation for burst factor accounted for 48 percent of the total variation with a standard error of 1.03 . Burst was a complex function of tracheid length, cell-wall thickness, tracheid diameter, and lumen diameter.

As shown in Fig. 2, burst increased with increasing tracheid length for all levels of cell-wall thickness and tracheid diameter. The level and the slope of the relationship of burst to tracheid length increased with increasing cell-wall thickness and decreased with increasing tracheid diameter.

All significant variables considered, burst strength was greatest in sheets made from fiber refined from wood having long tracheids with narrow diameters and thiok cell walls. 


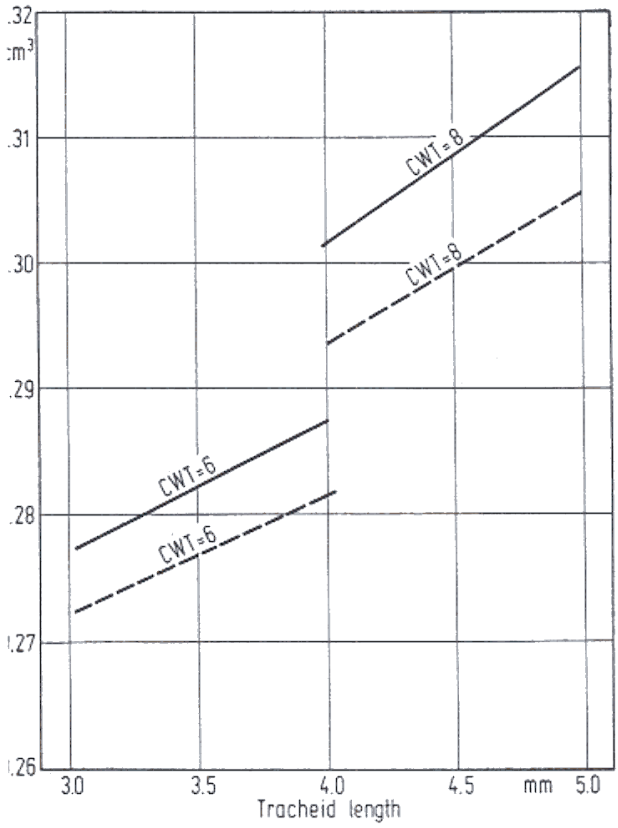

Fig. 1. Effect of tracheid length, cell-wall thickness (in micrometers), and tracheid diameter on sheet density. The dotted lines in this figure and in Figs. 2 through 4 plot tracheids having outside diameters of 49 micrometers. The solid lines plot tracheids having outside diameters of 42 micrometers.

Fig. 2. Effect of tracheid length, cell-wall thickness, and tracheid diameter on burst factor.

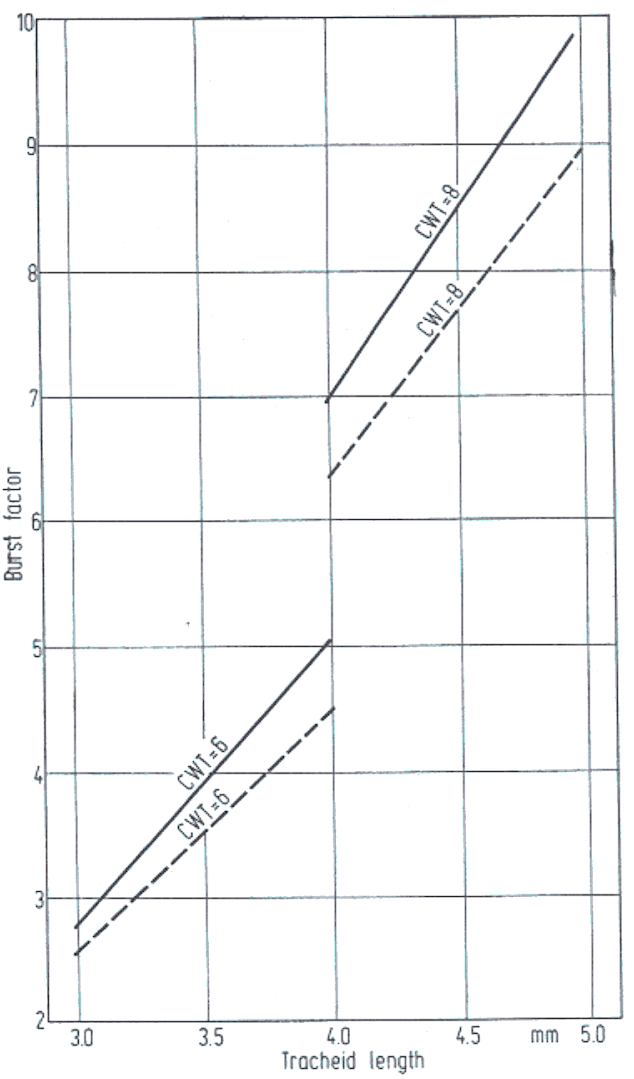

\section{Tear Factor}

Eq. (3) accounted for 56 percent of the variation in tear strength. The standard error of the estimate was 10.1. Tear factor was a complex function of lumen diameter, tracheid diameter, and cell-wall thickness. Tracheid length did not prove significant.

From Eq. (3) and Fig. 3, tear factor increased in a curvilinear manner with increasing cell-wall thickness for tracheids of large diameter, while it decreased slightly with increasing wall thickness for tracheids of small diameter. For a given wall thickness, tear factor increased with decreasing tracheid diameter.

All factors considered, tear factor was increased by using fiber refined from wood having narrow tracheids with thick walls.

\section{Breaking Length}

This property was related to a function of tracheid length, lumen diameter, tracheid diameter, and cell-wall thickness. Eq. (4) accounted for 74 percent of the variation, with a standard error of $\mathbf{1 3 3 . 2}$.

As shown in Fig. 4, breaking length increased with increasing tracheid length for all sampled levels of tracheid diameter and cell-wall thickness. Both the level and the slope of the breaking-length/tracheid-length relationship increased with 
increasing cell-wall thickness. Only the level increased with decreasing tracheid diameter.

All variables considered, breaking length was increased by using fiber refined from wood having long, narrow tracheids with thick walls.
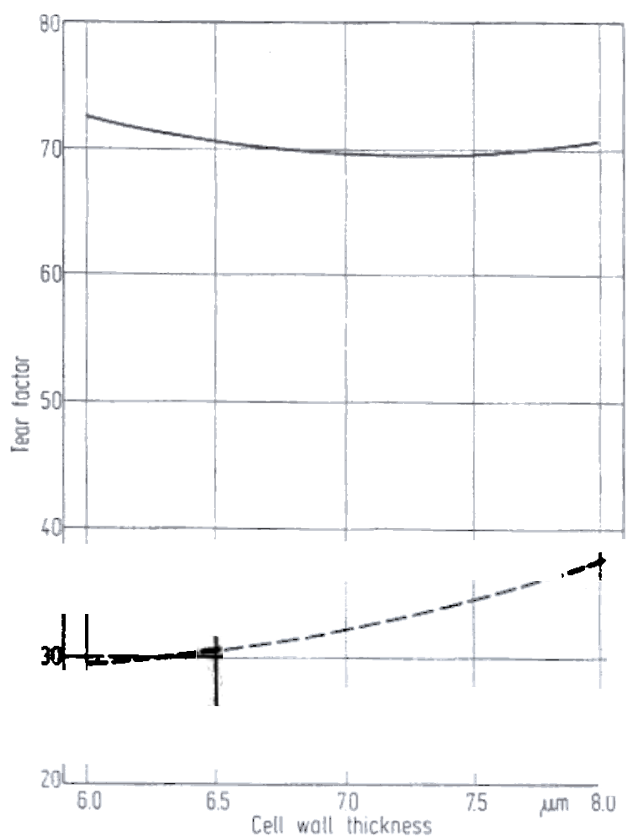

Fig. 3. Effect of cell-wall thickness and tracheid diameter on tear factor.

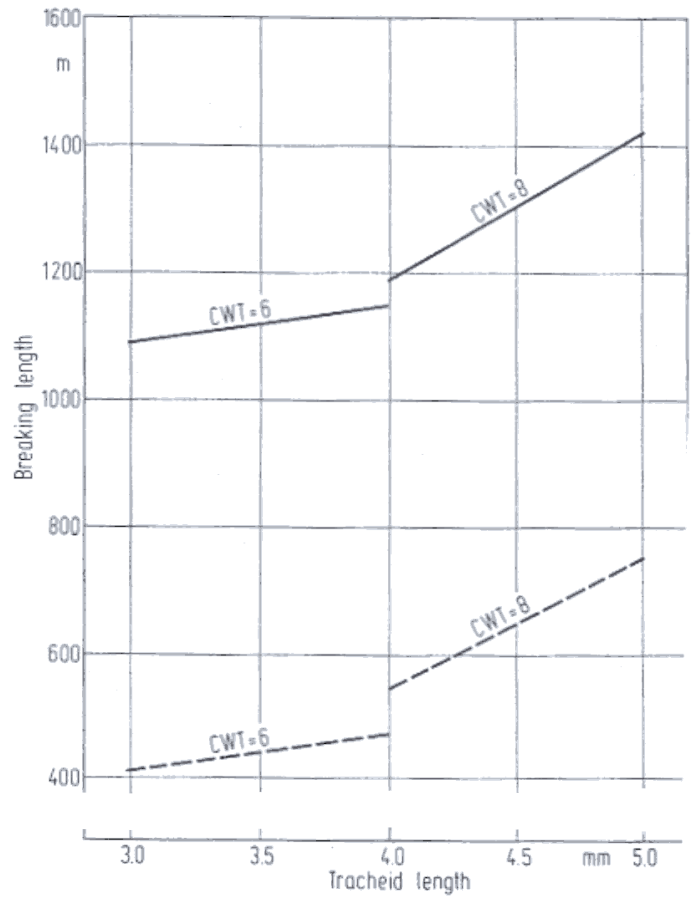

Fig. 4, Effect of tracheid length, cell-wall thick ness, and tracheid diameter on breaking length

\section{Discussion}

ATACK and MAY [1963] have described three phases of mechanical breakdown during the reduction of ohipe to fiber by double-disk refining. The first phase, occurring in the breaker-bar section, produces slender, matchstiok fragments whose major ares lie in the direction of the wood grain. In a second phase these fragments are processed into partially or completely separated fibers. Lastly, the fibers are refined into papermaking pulp. During this final phase, additional refining may oocur on the disk periphery by visco-elastic deformation of cylindrical fiber clumps [MAY, MORRIs, ATAOK 1863].

FORGAC8 [1963] has demonstrated that coherence and strength development in paper from groundwood are principally provided by ribbon-like, fibrillar partioles consisting mainly of the $S$, layer of the cell wall. Since such particles are highly flexible and deformable, they are brought into close contact with neighboring partioles by the surface tension forces aoting on them during drying. Thus, conditions favorable to hydrogen bonding are created. These ribbon-like particles were shown to be derived from the parent tracheids by unrevelling of the $S_{2}$ layer after propagation of cracks in the direction of the $S_{2}$ helix. 
FORG $\triangle$ Cs contends that unravelling results from rolling of intact isolated fibers - fiber bundles between the refiner plates. With chunks or fragmented parts of acheids, the chanoe of unravelling is reduced since the available lengths of the , layer in the direction of the helix may be too small to promote propagation of lits.

Microscopic examination of the pulps used in the present study, and strength sterminations of handsheets made from them, confirm the observations of ORGACB. Pulps containing well-soparated fibers with a high proportion of ribbons ad fibrils characteristically resulted in stronger handshoets than those from pulps intaining poorly separated fibers and chunks and low proportions of ribbons.

It seems possible that ribbons are formed through an interaction between foroes sveloped within an intect fiber during refining and the morphological charactertics of the fiber.

Although an exact theoretical stress analysis is confounded by thermo- and ydrodynamic effects and the anisotropic nature of fibers, an approximate soluon can be developed that is in reasonable agreement with the observed morphologiIl characteristics and handsheet strength.

Consider a uniform, smooth-sided, right-oylindrical, intect fiber consisting of aly the $S_{2}$ layer and having outside diameter $d_{0}$, inside diameter $d_{1}$, and length $L$. ssume that during the latter phases of refining the fiber becomes radially aligned etween the surfaces of two counter-rotating disks of radius $R$ revolving at speed $S$ 7ig. 5A). If there is no slippage, the fiber tonds to rotate about its longitudinal $x$ is $X-X^{\prime}$ at a velocity proportional to the rotational velocity of the disk at istance $R^{\prime}$ from disk center. Because the velocity of the disk varies directly with se disk radius, the rotational velocity at point $B^{\prime}$ on the fiber is greater than the elocity at point $B$, i.e., the radius of the disk is slightly greater at point $B^{\prime}$ than $t$ point $B$. Since the fiber tends to rotate a greater distance per unit time at oint $B^{\prime}$ than at point $B$, it is acted upon by a couple of equal numerical moment ut opposite sign. Under these conditions, the fiber may be analyzed as a hollow ircular shaft stressed in torsion.

If the undeformed fiber is considered to be held in mechanical equilibrium, ig. 5B approximates the force relationships existing within it. Under torsion, he shaft is twisted by a couple $P-P^{\prime}$. The magnitude of the oouple will be a inction of the difference between the rotational velocities at distance $L$ apart. lements of the surface become helices of angle $a$, and a radius is rotated through an ngle $b$ in length $L$. The state of stress of an element from the surface is pure shear Fig. 5C). Pure tension of the same magnitude as the shear stress is produced cross the plane $A-A^{\prime}$ at an angle of $45^{\circ}$ with the direction of the shear stress. here is an equal compressive stress on a plane $B-B^{\prime}$ at right angles to the tension lane. The stress in shear on the outer surface of a hollow, circular cylinder in orsion is given by

There:

$$
B_{\varepsilon}=\frac{16(T)\left(d_{\alpha}\right)}{\pi\left(d_{0}^{4}-d_{i}^{(T)}\right.}
$$

$\therefore=$ strow in shear, $T=$ toreional moment, $d_{0}=$ outeide diameter, $d_{1}=$ inaide diameter.

As previously noted, ribbons are produced when the $\mathcal{B}_{\mathbf{2}}$ layer of the tracheid rall is first cracked parallel to the fibril helix (angle $F$, Fig. 6C) and then unwound. 
It is generally held that the cell-wall microfibrils adhere strongly in large aggregates - termed fibrils - and that a zone of weakness exists between these aggregatee. To produce the deaired orack, the cell wall must be stressed in excess of the tensile or shear strength of the zone of weakness.
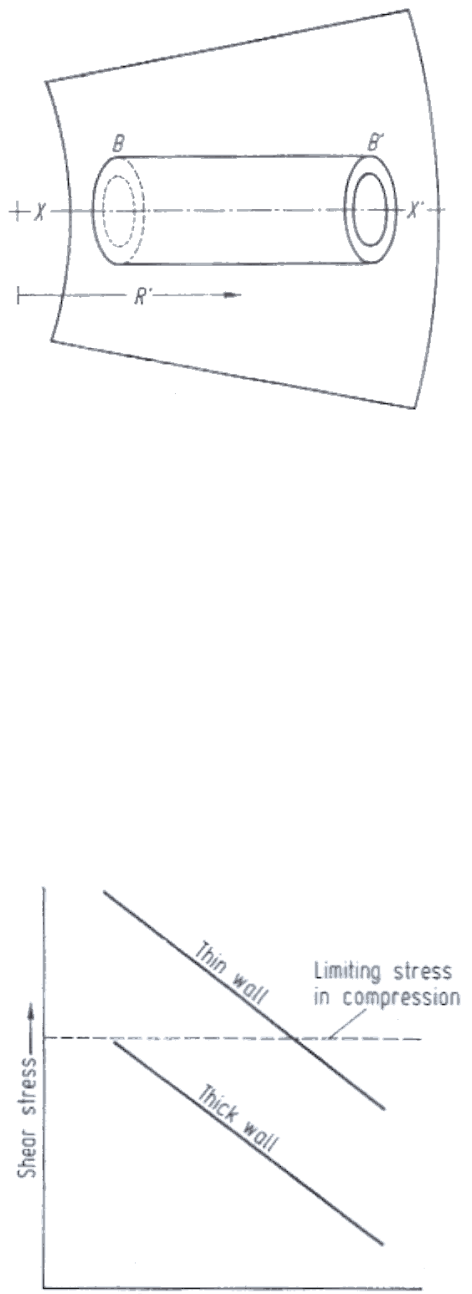

Outside diameter $\longrightarrow$

d

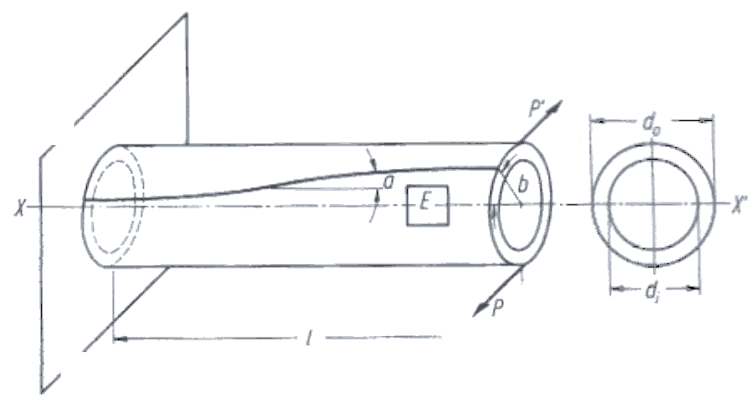

b
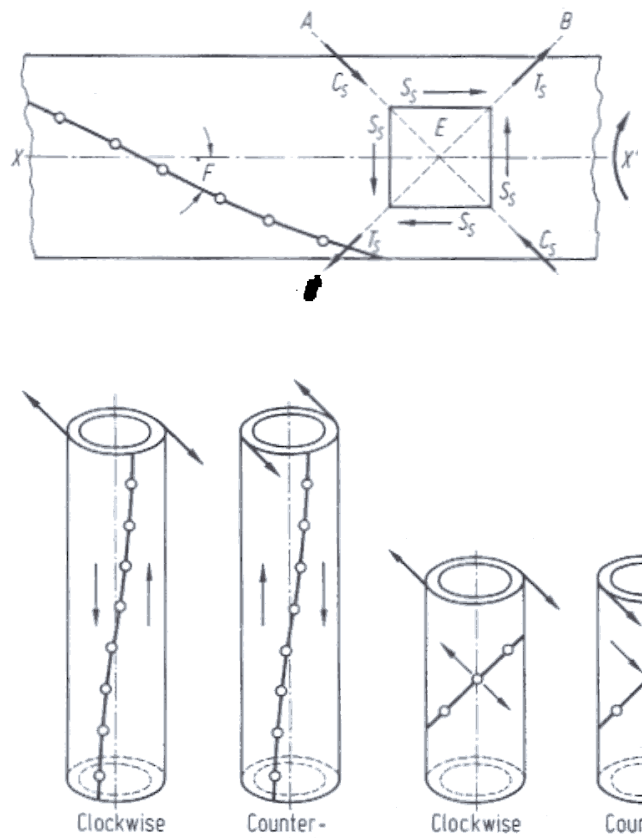

Counter clockwise

Long fiber

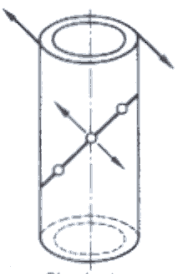

Clockwise

Short fiber

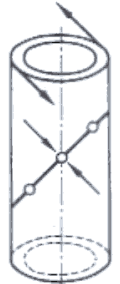

Counter-

clockwise

e

Fig. 5. Foroe relationships within an intact fiber during refining

For given torsional moment, shearing stresees $B_{8}$ of equal magnitude are introduoed parallel and perpendicular to the axis of the particle. They are accompanied by diagonal tensile $\left(T_{\mathrm{a}}\right)$ and compressive $\left(C_{\mathrm{a}}\right)$ stresses of equal magnitude.

Since the fiber is a nonbrittle, visco-elastic material, failure in shear perpendicular to the rotational axis is unlikely. The equation and Fig. 5D show that a cy. 
Ider with small outside diameter develops greater stress than a large-diameter linder when subjected to a given torsional moment. For a given outside diameter, ress is greater in thin-walled than in thick-walled shafts. If the stress level exeds the strength in compression (dotted line in Fig. 5D) before the strengths in wrallel shear or diagonal tension are exceeded, failure is likely to occur by diagonal, sckling. Thus, failure by diagonal buckling typically occurs in thin-walled, rge-diameter fibers. As a result, cracks do not form, and the fiber is unable to lwind into the desired ribbon.

If the strength in shear parallel to the fiber axis or in diagonal tension is exeded before the strength in diagonal compression, cracks can form parallel to e fibril helix and permit subsequent unwinding through visco-elastic deformasns or pure rolling. Thick-walled fibers of small outside diameter favor this ilure mechanism, since the stress level tends not to exceed the strength in diainal compression.

If, for a fiber of given diameter and wall thickness, the zone of weakness delisated by the fibril helix is nearly parallel to the parallel shearing stress (angle $F$ Fig. 5C is small), the strength in shear parallel to the fiber axis may be exceeded. ong fibers, because of their relatively small fibril angle, are prone to this failure pe if the torque is applied in either clockwise or counterclockwise direction ig. $5 \mathrm{E}$ ). Shorter fibers with characteristically larger fibril angles tend to fail by agonal tension when the torque is applied in a clockwise direction. With such jers, the strength in tension would be exceeded before the parallel shearing rength. A short fiber twisted counterclockwise would tend to buckle, since the ear plane is not highly stressed and the plane of weakness is stressed in compreson. Conditions are more favorable for ribbon formation with a long fiber than ith a short fiber because of higher stresses resulting from the greater differential tational velocity between the two ends. Furthermore, long fibers have better lances of attaining a true axial alignment than do short fibers. Clockwise rotation the fibers appears desirable since the induced stresses are in a favorable direction ith respect to the zone of weakness over a greater range of fiber lengths.

This analysis of torsional stresses applied to a cylindrical fiber during process$g$ agrees with the experimental results in terms of optimum tracheid dimensions $r$ improving properties of handsheets.

\section{References}

CACK, D., and W. D. MAY : Mechanical reduction of chips by double-disk refining. Pulp Pap. Mag. Can. 64 (1963) No. C, T75/T83, T118.

JRGACs, O. L.: The characterization of mochanical pulp. Pulp Pap. Mag. Can. 64 (1963) No. C, T88/T118.

AT, W. D., E. L. MORRIS and D. ATACK : Dynamics of a visco-elastic wear particle between sliding surfaces. J. Appl. Phys. 84 (1963) 1920/1928.

oMruIIN, C. W.: Groes wood characteristice affecting properties of handsheets made from Loblolly pine refiner groundwood. TAPPI 51 (1968) 51/56.

(Rocoived November 6, 1968)

Chardes W. MoMnulx, Wood Scientist, Southern Forest Experiment Station, USDA Forest Service, Alexandria, Louisiana. 